\title{
Effect of pH on metabolite excretion and cell morphology of Euglena gracilis under dark, anaerobic conditions
}

Kazumasa Yoshioka

Meiji Daigaku

Kengo Suzuki

euglena Co Ltd

Takashi Osanai ( $\nabla$ tosanai@meiji.ac.jp )

Meiji University https://orcid.org/0000-0003-2229-6028

\section{Research}

Keywords: anaerobic conditions, Euglena gracilis, fermentation, glutamate, glutamine, succinate

Posted Date: February 13th, 2020

DOI: https://doi.org/10.21203/rs.2.23456/v1

License: (c) (i) This work is licensed under a Creative Commons Attribution 4.0 International License.

Read Full License

Version of Record: A version of this preprint was published at Algal Research on October 1st, 2020. See the published version at https://doi.org/10.1016/j.algal.2020.102084. 


\section{Abstract}

\section{Background}

Euglena gracilis is a unicellular eukaryotic microalgae found in aquatic environments. It can adapt its morphology in response to various environmental stress factors such as changes in temperature, light, and ion concentrations. E. gracilis cells excrete succinate and amino acids under dark and anaerobic conditions; however, only a few studies on the effect of these conditions on the cell morphology of $E$. gracilis have been conducted thus far. In the present study, we aimed to evaluate the effects of $\mathrm{pH}$ on succinate, glutamine and glutamate production in E. gracilis and the correlation between the levels of these metabolites and cell morphology under dark, anaerobic conditions.

Results

The production of succinate, glutamine and glutamate by E. gracilis was $\mathrm{pH}$ dependent. Glutamate and glutamine excretion increased under acidic conditions ( $\mathrm{pH} 3-5)$, irrespective of the buffer salts. On the contrary, succinate production depended on the buffer salts; succinate levels were higher when GTA or citrate buffer were used and were lower when acetate buffer was used ( $\mathrm{pH} 4$ or 5). The number of spindle cells tended to increase under acidic conditions and the aspect ratio of the cells was positively correlated with glutamine and glutamate levels. Increase in cell density particularly enhanced glutamine and succinate production; in particular, the succinate titre reached $1.5 \mathrm{~g} / \mathrm{L}$, which is the highest reported level of succinate produced from photosynthetic eukaryotes till date.

\section{Conclusions}

Our findings indicate that $\mathrm{pH}$ of the media alters metabolite production and cell morphology of $E$. gracilis cells under dark, anaerobic conditions. A deeper understanding of eukaryotic fermentation will benefit the biorefinery industry, mainly for the production of value-added products using anaerobic microorganisms.

\section{Background}

Euglena gracilis is a unicellular eukaryotic microalga of the genus Euglena. E. gracilis cells possess unique characteristics of both plants and animals-both flagellar movement and photosynthesis within the chloroplasts can be observed in this organism. Euglena has attracted the attention of both researchers and the industry because of its ability to produce valuable products such as wax esters, paramylon, and organic acids. E. gracilis cells fix carbon dioxide and accumulate paramylon, which is an insoluble $\beta-1,3-g l u c a n$ [1]. Paramylon stimulates immune activity [2] and is effective in the treatment and prevention of infectious diseases, allergies, and arthritis [3,4]. Paramylon is accumulated in the presence of light and under aerobic conditions and is degraded under dark, anaerobic conditions. Paramylon degradation produces wax esters consisting of C14:0 saturated fatty acids, myristic acid, and myristyl alcohol [5]. Biodiesel and jet fuels are developed from wax esters, and recently, there have been increased efforts toward elucidating the practical uses of wax esters. Under aerobic conditions, E. gracilis cells 
accumulate amino acids at high levels, including methionine, an essential amino acid for humans [6]. E. gracilis cells also contain all the essential vitamins and polyunsaturated fatty acids (docosahexaenoic acid and eicosapentaenoic acid), which are nutritionally important $[7,8]$. Therefore, E. gracilis cells have wide applications in the nutritional, healthcare, energy, and environmental sectors.

In addition to the metabolites accumulated in the cells, E. gracilis can excrete value-added metabolites into the extracellular environment. Under dark, anaerobic conditions, nitrogen-starved E. gracilis cells excrete succinate, which is a precursor of many valuable products such as nanofibers and bioplastic resources $[9,10]$. At least 38 metabolites including various amino acids are excreted under dark, anaerobic conditions and glutamate is produced in a $\left(\mathrm{NH}_{3}\right)_{2} \mathrm{HPO}_{4}$-dependent manner [11]. The highest succinate titre achieved is $870 \mathrm{mg} / \mathrm{L}$, excreted from nitrogen-starved E. gracilis cells [10]. The highest titres of glutamate and glutamine are $265 \mathrm{mg} / \mathrm{L}$ and $56 \mathrm{mg} / \mathrm{L}$, respectively, excreted from E. gracilis cells grown in a pH-adjusted media with buffer salts [11]. Hence, although $\mathrm{E}$. gracilis has great potential for metabolite production, the relationship between the excreted metabolite levels and the $\mathrm{pH}$ remains obscure.

Cell morphology serves as an indicator of circadian rhythm, photosynthesis and respiratory capacity, cell cycle phase, and environmental conditions in E. gracilis cells [12]. Euglena species is predominantly spindle-shaped, but can also exist in spherical and elongated shapes [13]. Euglenoids exhibit a deformation phenomenon, such as aperiodic contraction and re-expansion, known as euglenoid movement [14]. Euglenoids display at least three types of morphologies-rounded, elongated, and bent [14]. Euglenoids exhibit diverse cell morphologies and their mobility and shape depend on various physical factors such as light, temperature, mechanical stimulations [15-17] and chemical factors such as organic acids and cations [18-21]. The most well-known factor causing euglenoid movement is light stimulation, particularly blue light [17], which causes a reversal of the direction of motion. E. gracilis cells also change their shape twice a day when grown under the synchronizing effect of a daily light-dark cycle [21]. E. gracilis cells change their cell morphology depending on the external environment. However, the $\mathrm{pH}$ dependency of their cell shapes under dark, anaerobic conditions is not understood and the relationship between morphology and metabolite production has not been examined.

In this study, we investigated the anaerobic production of glutamate, glutamine and succinate by $\mathrm{E}$. gracilis, which are of importance to the biorefinery industry. We also examined the effects of $\mathrm{pH}$ on the production of these metabolites and the relationship between metabolite production and cell morphology under dark, anaerobic conditions.

\section{Results}

pH-dependent production of glutamate, glutamine, and succinate by E. gracilis under dark, anaerobic conditions 
To clarify and confirm the $\mathrm{pH}$-dependency for metabolite production by E. gracilis, we performed three

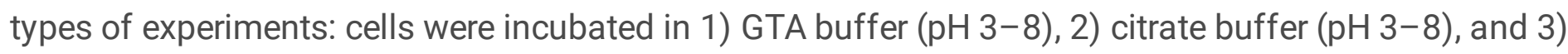
other commonly used buffers (glycine buffer for $\mathrm{pH} 3$, acetate buffer for $\mathrm{pH} 4$ and 5 , citrate buffer for $\mathrm{pH}$ 6 and HEPES buffer for $\mathrm{pH} 7$ and 8) under dark, anaerobic conditions. After incubation for 3 days, the levels of glutamate, glutamine, and succinate in the media were quantified. Glutamate levels were lower in the GTA and citrate buffers at pH 6-8 than those at pH 3-5 (Fig. 1A and B). Glutamate production was repressed in the glycine buffer ( $\mathrm{pH} 3$ ) but was less affected by the types of buffer (Fig. 1C). Glutamine levels were increased at acidic $\mathrm{pH}(\mathrm{pH} 3-5)$ irrespective of the buffer types (Fig. 1D-F). Citrate buffer slightly repressed glutamine production at pH 3-5 (Fig. 1E) compared to GTA and the commonly used buffers (Fig. 1D and 1F). The maximum titres of glutamate and glutamine were $78 \mathrm{mg} / \mathrm{L}$ in GTA buffer $(\mathrm{pH} 3)$ and $88 \mathrm{mg} / \mathrm{L}$ in GTA buffer (pH 5), respectively (Fig. 1A and 1D).

Succinate levels were affected by the buffer types (Fig. 2A-C). The highest succinate levels were observed in cells incubated in citrate buffer at pH 6-8 (Fig. 2B). The succinate titres were high under several incubation conditions: $183 \mathrm{mg} / \mathrm{L}$ in GTA buffer $(\mathrm{pH} 5), 165 \mathrm{mg} / \mathrm{L}$ in citrate buffer $(\mathrm{pH} 6)$ and $177 \mathrm{mg} / \mathrm{L}$ in HEPES buffer (pH 7) (Fig. 2A-C). Succinate production was less affected by the pH of GTA buffer (Fig. 2A), however, it was higher at neutral $\mathrm{pH}(\mathrm{pH} 6-8)$ than at acidic $\mathrm{pH}(\mathrm{pH} 3-5)$ in the citrate buffer (Fig. 2B). Acetate buffer intensely decreased the succinate levels to $6 \mathrm{mg} / \mathrm{L}$ at pH 4 (Fig. 2C).

The $\mathrm{pH}$ of the buffers before and after dark, anaerobic incubation was measured. $\mathrm{pH}$ of the buffers was altered from the initial $\mathrm{pH}$ during dark, anaerobic incubation within a range of $\mathrm{pH} 4-7$ (Fig. 2D-F). Interestingly, glycine buffer ( $\mathrm{pH} 3$ ) after dark, anaerobic incubation was strikingly alkalinised from $\mathrm{pH} 3$ to 6 (Fig. 2F). As glycine is an intermediate of photorespiration, $\mathrm{NH}_{3}$ might be possibly produced by glycine decarboxylase in the photorespiration pathway. $\mathrm{NH}_{3}$ levels in the glycine buffer $(\mathrm{pH} 3)$ were quantified after dark, anaerobic incubation and the $\mathrm{NH}_{3}$ titre was observed to be approximately $17 \mathrm{mg} / \mathrm{L}$, whereas, it was lesser than $2 \mathrm{mg} / \mathrm{L}$ in the HEPES buffer (pH 8) (Fig. 2G).

pH-dependent morphological changes in E. gracilis cells under dark, anaerobic conditions

In addition to the metabolite analysis, morphology of E. gracilis cells incubated under dark, anaerobic conditions for 3 days was observed via microscopy and analysed by Image $\mathrm{J}$ software. Brown granules were frequently observed in the cells cultivated at $\mathrm{pH} 3-5$, but less frequently at $\mathrm{pH} 6-8$ (Fig. 3A). Chloroplasts were widely spread throughout the cells at $\mathrm{pH} 7$ and 8 , compared to that in cells cultivated at pH 3-6 (Fig. 3A). In case of the citrate buffer, brown granules were absent at all the pH conditions tested (Fig. 3B). Chloroplasts were also widely spread at neutral pH (pH 7 and 8) (Fig. 3B). In case of the commonly used buffers, brown granules increased, and spindle cells were frequently observed in the acetate buffer ( $\mathrm{pH} 4$ and 5) (Fig. $3 \mathrm{C}$ ). Chloroplasts in the HEPES buffer were similarly extended at neutral $\mathrm{pH}$ ( $\mathrm{pH} 7$ and 8) (Fig. 3C), but were relatively aggregated compared to the GTA and citrate buffers (Fig. 3A, B). 
E. gracilis cells exhibited a spindle shape at acidic $\mathrm{pH}(\mathrm{pH} 3-5)$ and a spherical shape at $\mathrm{pH}$ 6-8 in the GTA buffer (Fig. $3 \mathrm{~A}$ and $4 \mathrm{~A}$ ). The ratios of spindle cell at pH 3 and 4 were $57 \%$ and $37 \%$, respectively and the aspect ratio was the highest in the GTA buffer at pH 3 (Fig. 4A). In contrast, more than $90 \%$ of the cells exhibited spherical shape in the GTA buffer at pH 5-8 (Fig. 4A). E. gracilis cells were spherical in the citrate buffer irrespective of the $\mathrm{pH}$ (Fig. 3B and 4B). E. gracilis cells maintained spherical shape in the glycine buffer $(\mathrm{pH} 3)$ and HEPES buffer ( $\mathrm{pH} 7$ and 8) but spindle cells were dominant in the acetate buffer ( $\mathrm{pH} 4$ and 5) (Fig. 3C and 4C). Aspect ratio of the cells was in the range of 1.5-1.6 in the acetate buffer (pH 4 and 5) (Fig. 4C). Cell area after dark, anaerobic incubation was almost similar irrespective of the buffer types used and pH conditions (Fig. 4D-F).

Relationship among metabolite levels and cell morphology and cell density of E. gracilis under dark, anaerobic conditions

For biological application, increased cell density for fermentation reduces cost, input energy and materials. E. gracilis cells with increased density by 7 - or 10 -fold $\left(\mathrm{OD}_{730}=140\right.$ or 200$)$ were similarly incubated in the citrate buffer $(\mathrm{pH} 6)$ and the production of the three metabolites and cell morphology were examined. Glutamate levels were not increased at $\mathrm{OD}_{730}=140$ and only increased by 1.5 -fold at $O D_{730}=200$, compared to $O D_{730}=20$ (Fig. 5A). Glutamine and succinate levels increased in a cell densitydependent manner, whose maximum levels reached $163 \mathrm{mg} / \mathrm{L}$ and $1.5 \mathrm{~g} / \mathrm{L}$ at $O D_{730}=200$, respectively (Fig. 5B and 5C). The pH of the media was maintained at 6 during dark, anaerobic conditions irrespective of the cell density (Fig. 5D). Interestingly, spindle cells increased in a density-dependent manner, approximately $58 \%$ of the cells exhibited spindle shapes containing brown granules at $\mathrm{OD}_{730}=200$ (Fig. 5E and F). Cell area was also maintained constant irrespective of the cell density (Fig. 5G).

Altered relationship dependent on buffer types, $\mathrm{pH}$ of the media, and cell concentrations

Finally, we analysed the data to reveal the relationship between the metabolite levels, $\mathrm{pH}$ of the media and parameters of cell morphology with the calculation of correlation coefficients. In all the dark, anaerobic incubation conditions tested, glutamate and glutamine levels were positively correlated with each other and their levels were negatively correlated with $\mathrm{pH}$ of the media (Fig. 6A-D). Aspect ratio was negatively correlated with the $\mathrm{pH}$ of the media and positively correlated with glutamate and glutamine levels (Fig. 6A, B, D), except for the incubation in citrate buffer, where the correlation between the aspect ratio and glutamate/glutamine levels was absent (Fig. 6B). Succinate levels were positively correlated with glutamine and glutamate levels in the GTA buffer (Fig. 6A), whereas negatively correlated with them in the citrate and commonly used buffers (Fig. 6B and C). Correlation of succinate with pH and aspect ratio were varied in different incubation conditions (Fig. 6A-D).

\section{Discussion}

Amino acid and organic acid levels inside E. gracilis cells are altered by changes in light and aeration [22, 23]. Metabolomic analysis comparing three growth conditions-aerobic dark, aerobic light and anaerobic 
dark conditions, shows that only 4 out of 56 metabolites, including succinate, were increased in the E. gracilis cells grown under anaerobic dark conditions [22]. Levels of most of the amino acids in the cells except lysine decrease under anaerobic dark conditions, and glutamate and glutamine are undetectable at these conditions [22]. The data from the metabolomic analysis suggested that the excretion step may be the rate-limiting factor for succinate production, but glutamate and glutamine are easily exported from E. gracilis cells under dark, anaerobic conditions. Hence, the results of excreted metabolite analysis during dark, anaerobic conditions were different from that of the analysis of intracellular metabolites.

Glutamate and glutamine levels at acidic conditions ( $\mathrm{pH} 3-4)$ were higher than those at neutral conditions (Fig. 1). The pH dependency of succinate production varied among the three types of experiments (Fig. $2 \mathrm{~A}-\mathrm{C}$ ). These results demonstrate that glutamate and glutamine production is dependent on the $\mathrm{pH}$ of the media and succinate production is affected by the buffer salts. A previous study revealed the $\mathrm{pH}$-dependency of glutamate production by $\mathrm{E}$. gracilis at neutral $\mathrm{pH}$ [11]. In the previous study, pH was adjusted using 3-morpholinopropanesulfonic acid (MOPS) buffer, and similar results for glutamate production were observed with the use of HEPES buffer (compared to the glutamate levels at pH 7 and 8 in Fig. 1C). However, incubation of the cells in the GTA and citrate buffers diminished the difference between glutamate levels at pH 7 and 8 (Fig. 1A and 1B). Unlike the MOPS and HEPES buffers, Tris reduces the cell growth [24] and citrate inhibits lipid accumulation in microalgae [25], indicating that the buffer salts affect cell metabolism under dark, anaerobic conditions and must be optimised to increase the metabolite productivity of E. gracilis under dark, anaerobic conditions. The optimum $\mathrm{pH}$ of glutamate synthase in E. gracilis is 7.5 [26], but glutamate production was accelerated under acidic conditions (Fig. 1A-C), suggesting that the optimum $\mathrm{pH}$ was not the only factor determining metabolite levels.

Succinate production from E. gracilis exhibited dependency on the type of the buffer (Fig. 2A-C). Depending on the buffer salts, correlation of succinate and pH of the media varied (Fig. 6A-D), and acetate buffer strikingly repressed succinate production (Fig. 2C). Acetate assimilated into E. gracilis cells is used in the glyoxylate pathway [27]. Succinate is generated through the glyoxylate pathway; however, resultant succinate is converted into wax esters under dark, anaerobic conditions [5], possibly decreasing the succinate levels. Considering the cost and titres, citrate buffer is suitable for succinate production by E. gracilis. The maximum succinate titre, $1.5 \mathrm{~g} / \mathrm{L}$, from E. gracilis cells incubated in citrate buffer $(\mathrm{pH} 6)$ obtained in this study (Fig. 5C), is the highest reported among the succinate production studies using photosynthetic eukaryotes till date. Interestingly, dark, anaerobic incubation in glycine buffer alkalised the media (Fig. 2F), possibly assimilated glycine was metabolised to generate ammonium through the photorespiratory pathway (Fig. 2G). Thus, our analysis demonstrated how the succinate levels vary with the difference in buffer types in E. gracilis cells incubated under dark, anaerobic conditions.

E. gracilis cells perform elongation and contraction called euglenoid movement under aerobic conditions [28]. Although cell morphology of E. gracilis changes frequently depending on the growth conditions [14, 21], E. gracilis cells form spherical cysts in response to various stresses [29-32]. In our study, the increase in the ratio of spindle to spherical shaped cells at $\mathrm{pH} 3-5$ was more than that at $\mathrm{pH} 6-8$ in the GTA buffer 
(Fig. 3A and $4 \mathrm{~A}$ ) and the aspect ratio was negatively correlated with the $\mathrm{pH}$ of the media (Fig. 6). At neutral pH conditions, all the cells exhibited spherical shapes in all of the buffer types tested (Figs. 3 and 4). However, in acidic conditions, cell shapes were dependent on the buffer salts; acetate buffer increased spindle cells and citrate and glycine buffers increased spherical cells, compared to the cells in the GTA buffer (Figs. 3 and 4). These results demonstrate that cell shapes are dependent on $\mathrm{pH}$ at neutral $\mathrm{pH}$ conditions and buffer salts at acidic conditions. Cyst formation of $\mathrm{E}$. gracilis requires mucus sheath formation, which is repressed under acidic conditions [33]. Hence, cyst formation (conversion to spherical cells) may be interrupted at acidic conditions due to the lack of mucus sheath, leading to the formation of spindle cells at acidic conditions. Nevertheless of these morphological changes, cell area remained constant at all of the conditions tested (Fig. 4F and 5G), indicating the homeostasis of cell volumes under dark, anaerobic conditions. Brown granules were observed in cells incubated at acidic $\mathrm{pH}(\mathrm{pH} 3-5)$, and were located closer to the cell surface and adjacent to other organelles (Fig. 3). In E. gracilis cultivated under dark conditions, chloroplasts are degraded, but brown granules remain in the cells [34]. These granules are reported to be massive membrane structures generated from degraded thylakoids [34]. In our study, the brown granules were less frequent at neutral $\mathrm{pH}(\mathrm{pH} 7$ and 8). The negative correlation between brown granules and green-coloured chloroplasts support the idea that brown granules are derived from chloroplasts. Correlation analysis revealed that the relationship between the levels of the three metabolites, $\mathrm{pH}$ of the media and parameters of cell morphology was varied by buffer salts and cell concentrations. Only positive correlation between glutamate and glutamine and negative correlation between glutamine/glutamate and $\mathrm{pH}$ of the media were consistent from the data of the four experiments (Fig. 6A-D). The current results demonstrate that the relationship between the metabolite productions and cell morphology is dependent on buffer types.

\section{Conclusions}

The present study showed that E. gracilis cells have great potential for the production of metabolites from carbon dioxide. We achieved the highest titre for succinate produced by eukaryotic microalgae to date. Further studies optimising cultivation conditions and scaling up the E. gracilis culture are necessary for the bioproduction of value-added products from carbon dioxide by E. gracilis.

\section{Methods}

Euglena strains and culture conditions

Euglena gracilis strain NIES-48 was obtained from the National Institute for Environmental Studies in Japan. E. gracilis cells were grown in modified $\mathrm{CM}$ medium (pH adjusted to 3.5) [11]. Cells were grown in liquid medium bubbled with $1 \%(\mathrm{v} / \mathrm{v}) \mathrm{CO}_{2}$ in the air and incubated in a plant growth chamber for preculture (TOMY, Tokyo, Japan) at $25{ }^{\circ} \mathrm{C}$ under $12 \mathrm{~h}$ light/dark conditions with white light at $\sim 40 \mu \mathrm{mol}$ photons $\mathrm{m}^{-2} \mathrm{~s}^{-1}$. After preculture, the cells were inoculated into $1 \mathrm{~L}$ of modified $\mathrm{CM}$ medium and cultivated using a magnetic stirrer in the plant growth chamber for approximately 15 days. Cell densities were measured at $\mathrm{OD}_{730}$ using a spectrophotometer UV-2400 (Shimadzu, Kyoto, Japan). 
Incubation under dark, anaerobic conditions and quantification of cell morphology parameters

Dark, anaerobic incubation was performed as described previously $[10,28]$ with certain modifications. E. gracilis cells were concentrated in $10 \mathrm{~mL}$ of $20 \mathrm{mM}$ buffer ranging from pH 3-8 at $\mathrm{OD}_{730}=20,140$ or 200 in a GC vial. GTA buffer, containing $20 \mathrm{mM}$ 3.3-dimethyl glutarate, $20 \mathrm{mM}$ tris (hydroxymethyl) aminomethane (Tris) and $20 \mathrm{mM}$ 2-amino-2-methyl-1,3-propanediol, was used for incubation in the range of $\mathrm{pH} 3-8 \mathrm{pH}$ of the GTA buffer was adjusted with $1 \mathrm{M}$ sodium hydroxide and $2 \mathrm{M}$ hydrochloric acid solutions. Additionally, the buffers consisted of glycine $\mathrm{HCl}(\mathrm{pH} 3)$, sodium acetate $(\mathrm{pH} 4$ and 5), sodium citrate (pH 6), and 4-(2-hydroxyethyl)-1-piperazineethanesulfonic acid (HEPES)-KOH (pH 7 and 8). After introduction of nitrogen gas for 3 min with a syringe, the GC-vial was sealed with a butyl rubber cap. The GC-vial was wrapped in an aluminium foil to maintain dark, anaerobic conditions and then incubated at $25^{\circ} \mathrm{C}$ for 3 days with shaking. After dark, anaerobic cultivation, cells were observed using a Leica DM 500 microscope (Leica Microsystems, Tokyo, Japan). Sixty cells were randomly selected and analyzed using the Leica Application Suite software, version 4.6. The pH levels of the supernatants were measured using a LAQUAact pH meter (Horiba, Kyoto, Japan). Cell morphology was measured, and cell areas were quantified using the image visualisation software ImageJ. If the length/width ratio, defined as aspect ratio (AR) was 1.3 or greater, then the cell was considered to be spindle shaped, whereas an AR less than 1.3 indicated the spherical shape of E. gracilis cells. The area of an individual cell and the length of the pixel size per micrometre were determined using the Image $\mathrm{J}$ software.

\section{Glutamate and Glutamine Quantification}

After dark, anaerobic incubation for 3 days, cells were removed by centrifugation (5,800 $\mathrm{g} \times 2 \mathrm{~min}$ at room temperature), and the supernatant was filtered by a membrane filter with $0.45 \mu \mathrm{m}$ pores (LMS, Tokyo, Japan). The filtrates were used for metabolite analysis. Glutamate and glutamine levels were quantified by a biosensor BF-7D (Oji Scientific Instruments, Hyogo, Japan) with a glutamate electrode (ED07-0004) and a glutamine electrode (ED07-0015). Enzyme reaction was performed at $37^{\circ} \mathrm{C}$ in a biosensor chamber and the standard curves were constructed with standard solutions purchased from Oji Scientific Instruments.

\section{Succinate Quantification}

Succinate was quantified by high-performance liquid chromatography as previously described with certain modifications [35]. After dark, anaerobic incubation, $1 \mathrm{ml}$ of filtrates was dried with a vacuum dryer CC-105 (TOMY, Tokyo, Japan), and resuspended in $97 \mu \mathrm{L} \mathrm{HClO}_{3}$ and $3 \mu \mathrm{L}$ of trichloroacetic acid (Wako, Osaka, Japan). Further, it was mixed in a vortex mixer for $10 \mathrm{~min}$, the mixture was centrifuged for 10 min at $20,500 \mathrm{~g} \times 2 \mathrm{~min}$. Supernatant $(100 \mu \mathrm{L})$ was used for HPLC analysis with LC-2000Plus Systems (JASCO, Tokyo, Japan).

Ammonia Quantification 
Sample preparation was performed in a manner similar to that used for glutamate, glutamine and succinate. Filtered supernatant $(150 \mu \mathrm{L})$ was dried with a vacuum dryer, and resuspended in $1.2 \mathrm{~mL}$ of $3 \%$ trichloroacetic acid solution. After centrifugation for $10 \mathrm{~min}$ at 20,500 $\mathrm{g} \times 2 \mathrm{~min}$, supernatant was commercially analyzed by Hokkaido University Global Facility Center with HPLC L-8900 (Hitachi High Tech Science, Tokyo, Japan).

Statistical analysis

Statistical analyses, calculation of means, standard deviation (SD), and correlation coefficients, were performed using Excel 2016 software (Microsoft, Seattle, WA, USA). We conducted statistical analysis using Tukey's HSD test for multiple comparisons and Student's t-test for differences between the two samples. $p$-value $<0.05$ was considered as statistically significant. Pearson correlation coefficient $(r-$ value) was visualised with the Cytoscape_ver3.7.2 software.

\section{Abbreviations}

AR, aspect ratio; HEPES, 4-(2-hydroxyethyl)-1-piperazineethanesulfonic acid; MOPS, 3morpholinopropanesulfonic acid; SD, standard deviation;

\section{Declarations}

\section{Ethics approval and consent to participate}

Not applicable

\section{Consent for publication}

Not applicable

\section{Availability of data and materials}

Not applicable

\section{Competing interests}

This study was also funded by euglena Co., Ltd (Tokyo, Japan). However, the funding sources did not affect the interpretation of the results in this study. 


\section{Funding}

This work was supported by the Ministry of Education, Culture, Sports, Science, and Technology, Japan; a grant to T.O. from ALCA from the Japan Science and Technology Agency [grant number JPMJAL1306]; and JSPS KAKENHI Grant-in-Aid for Scientific Research on Innovative Areas [grant number 16H06559]. This study was also funded by euglena Co., Ltd.

\section{Authors' contributions}

$\mathrm{KY}$ designed the research, conducted the experiments, analyzed the data, and wrote the manuscript, KS designed the research, and TO designed the research and wrote the manuscript.

\section{Acknowledgement}

The language of the manuscript was corrected twice by Editage Co. Ltd.

\section{References}

[1] Calvayrac R, Laval-Martin D, Briand J, Farineau J. Paramylon synthesis by Euglena gracilis photoheterotrophically grown under low $\mathrm{O}_{2}$ pressure. Planta. 1981;153:6-13. doi: https://doi.org/10.1007/BF00385311

[2] Russo R, Barsanti L, Evangelista V, Frassanito AM, Longo V, Pucci L, et al. Euglena gracilis paramylon activates human lymphocytes by upregulating pro-inflammatory factors. Food Sci Nutr. 2017;5:205-14. doi: $10.1002 /$ fsn3.383

[3] Watanabe T, Shimada R, Matsuyama A, Yuasa M, Sawamura H, Yoshida E, et al. Antitumor activity of the $\beta$-glucan paramylon from Euglena against preneoplastic colonic aberrant crypt foci in mice. Food Funct. 2013;4:1685-90. doi: 10.1039/c3fo60256g

[4] Suzuki K, Nakashima A, Igarashi M, Saito K, Konno M, Yamazaki N, et al. Euglena gracilis Z and its carbohydrate storage substance relieve arthritis symptoms by modulating Th17 immunity. PloS ONE. 2018;13:e0191462. doi: https://doi.org/10.1371/journal.pone.0191462

[5] Inui H, Miyatake K, Nakano Y, Kitaoka S. Wax ester fermentation in Euglena gracilis. FEBS Lett. 1982;150:89-93. doi: https://doi.org/10.1016/0014-5793(82)81310-0

[6] Kitaoka S and Hosotani K. Studies on culture conditions for the determination of the nutritive value of Euglena gracilis protein and the general and amino acid compositions of the cells. J Agric Chem Soc Jpn. 1977;51:477-82. doi: https://doi.org/10.1271/nogeikagaku1924.51.8_477 
[7] Baker ER, McLaughlin JJA, Hutner SH, DeAngelis B, Feingold S, Frank O, et al. Water-soluble vitamins in cells and spent culture supernatants of Poteriochromonas stipitata, Euglena gracilis, and Tetrahymena thermophila. Arch Microbiol. 1981;129:310-3. doi: https://doi.org/10.1007/BF00414703

[8] Hayashi M, Toda K, Kitaoka S. Enriching Euglena with unsaturated fatty acids. Biosci Biotechnol Biochem. 1993;57;352-3. doi: https://doi.org/10.1271/bbb.57.352

[9] Shibakami M, Tsubouchi G, Nakamura M, Hayashi M. Preparation of carboxylic acid-bearing

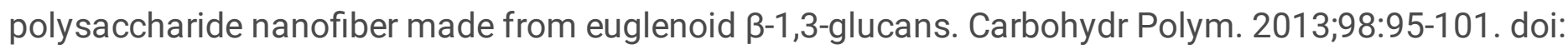
https://doi.org/10.1016/j.carbpol.2013.05.026

[10] Tomita Y, Yoshioka K, lijima H, Nakashima A, Iwata O, Suzuki K, et al. Succinate and lactate production from Euglena gracilis during dark, anaerobic conditions. Front Microbiol. 2016;7:2050. doi: https://doi.org/10.3389/fmicb.2016.02050

[11] Tomita Y, Takeya M, Suzuki K, Nitta N, Higuchi C, Marukawa-Hashimoto Y, et al. Amino acid excretion from Euglena gracilis cells in dark and anaerobic conditions. Algal Res. 2019;37:169-77. doi: https://doi.org/10.1016/j.algal.2018.11.017

[12] Li M, Muñoz HE, Goda K, Di Carlo D. Shape-based separation of microalga Euglena gracilis using inertial microfluidics. Sci Rep. 2017;7:10802. doi: https://doi.org/10.1038/s41598-017-10452-5

[13] Karnkowska-Ishikawa A, Milanowski R, Triemer RE, Zakryś B. A redescription of morphologically similar species from the genus Euglena: E. laciniata, E. sanguinea, E. sociabilis, and E. splendens ${ }^{1}$. J Phycol. 2013;49:616-26. doi: https://doi.org/10.1111/jpy.12072

[14] Suzaki T, Williamson, RE. Euglenoid movement in Euglena fusca: evidence for sliding between pellicular strips. Protoplasma. 1985;124:137-46. doi: https://doi.org/10.1007/BF01279733

[15] Pogo AO, Arce A. Synchronization of cell division in Euglena gracilis by heat shock. Exp Cell Res. 1964;36:390-7. doi: https://doi.org/10.1016/0014-4827(64)90217-4

[16] Mikolajczyk E, Diehn B. Mechanosensory responses and mechanoreception in Euglena gracilis. Acta Protozool. 1979;18:591-602.

[17] Doughty MJ, Grieser R, Diehn B. Photosensory transduction in the flagellated alga, Euglena gracilis. II. Evidence that blue light effects alteration in $\mathrm{Na}^{+} / \mathrm{K}^{+}$permeability of the photoreceptor membrane. Biochim Biophys Acta, Biomembr. 1980;602: 10-23. doi: https://doi.org/10.1016/0005-2736(80)90285-0

[18] Alexander G. The significance of hydrogen ion concentration in the biology of Euglena gracilis Klebs. Biol Bull. 1931;61:165-84. doi: https://www.jstor.org/stable/1537011

[19] Bates RC, Hurlbert RE. The effect of acetate on Euglena gracilis var. bacillaris as a function of environmental conditions. J Eukaryot Microbiol. 1970;17:134-8. doi: https://doi.org/10.1111/j.1550- 
[20] Votta JJ, Jahn TL, Levedahl BH. The mechanism of onset of the stationary phase in Euglena gracilis grown with $10 \mathrm{~mm}$ succinate: Intracellular pH values. J Eukaryot Microbiol. 1971;18:166-70. doi:https://doi.org/10.1111/j.1550-7408.1971.tb03301.x

[21] Lonergan TA. Regulation of Cell Shape in Euglena gracilis: I. Involvement of the biological clock, respiration, photosynthesis, and cytoskeleton. Plant Physiol. 1983;71: 719-30. doi: https://doi.org/10.1104/pp.71.4.719

[22] Matsuda F, Hayashi M, Kondo A. Comparative profiling analysis of central metabolites in Euglena gracilis under various cultivation conditions. Biosci Biotechnol Biochem. 2011;75:2253-6. doi: https://doi.org/10.1271/bbb.110482

[23] Hasan MT, Sun A, Mirzaei M, Téo J, Hobba G, Sunna A, et al. A comprehensive assessment of the biosynthetic pathways of ascorbate, a-tocopherol and free amino acids in Euglena gracilis var. saccharophila. Algal Res. 2017;27:140-51. doi: https://doi.org/10.1016/j.algal.2017.08.029

[24] Nguyen TT, Bui XT, Pham MD, Guo W, Ngo HH. Effect of Tris-(hydroxymethyl)-amino methane on microalgae biomass growth in a photobioreactor. Bioresour Technol. 2016;208:1-6. doi: https://doi.org/10.1016/j.biortech.2016.02.043

[25] Marudhupandi T, Gunasundari V, Kumar TTA, Tissera KRA. Influence of citrate on Chlorella vulgaris for biodiesel production. Biocatal Agric Biotechnol. 2014;3: 386-9. doi:

https://doi.org/10.1016/j.bcab.2014.03.008

[26] Miyatake K, Kitaoka S. NADH-dependent glutamate synthase in Euglena gracilis z. Agric Biol Chem. 1981;45:1727-9. doi: https://doi.org/10.1271/bbb1961.45.1727

[27] Woodward J, Merrett MJ. Induction potential for glyoxylate cycle enzymes during the cell cycle of Euglena gracilis. Eur J Biochem. 1975;55:555-9. doi: https://doi.org/10.1111/j.1432-1033.1975.tb02192.x

[28] Suzaki T. Euglenoid movement. Jpn J Protozool. 2004;37:169-90. doi: https://doi.org/10.18980/jjprotozool.37.2_169

[29] Tannreuther GW. Nutrition and reproduction in Euglena. Archiv für Entwicklungsmechanik der Organismen. 1923;52:367-83. doi: https://doi.org/10.1007/BF02093633

[30] Triemer RE. Role of golgi apparatus in mucilage production and cyst formation in Euglena gracilis (Euglennophyceae) ${ }^{1}$, J Phycol, 1980;16:46-52. doi: https://doi.org/10.1111/j.1529-8817.1980.tb02997.x

[31] Takenaka S, Kondo T, Nazeri S, Tamura Y, Tokunaga M, Tsuyama S, et al. Accumulation of trehalose as a compatible solute under osmotic stress in Euglena gracilis Z. J Eukaryot Microbiol. 1997;44:609-13. doi: https://doi.org/10.1111/j.1550-7408.1997.tb05967.x 
[32] Hindák F, Wolowski K, Hindáková A. Cysts and their formation in some neustonic Euglena species. Ann Limnol - Int J Lim. 2000;36:83-93. doi: https://doi.org/10.1051/limn/2000010

[33] Buetow DE. Morphology and ultrastructure of Euglena. In: Buetow DE, editor. The Biology of Euglena vol. 1. New York: Acad. Press;1968. p.109-84.

[34] Kashiyama Y, Kawahara J, Maruyama M, Kayama M, Nakazawa M, Tanifuji G, et al. An evolutionary transition of chloroplast degradation in euglenoids: heterotrophic digestion to secondary plastid senescence, Protistol. 2016;10:32-3.

[35] Yasuda $\mathrm{C}$, lijima $\mathrm{H}$, Sukigara $\mathrm{H}$, Osanai T. Incubation of cyanobacteria under dark, anaerobic conditions and quantification of the excreted organic acids by HPLC. Bio-protocol. 2017;7:e2257.doi: 10.21769/BioProtoc. 2257

\section{Figures}

Glutamate

(A)

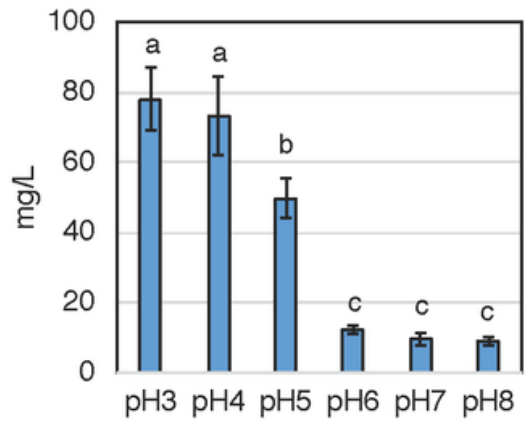

(B)

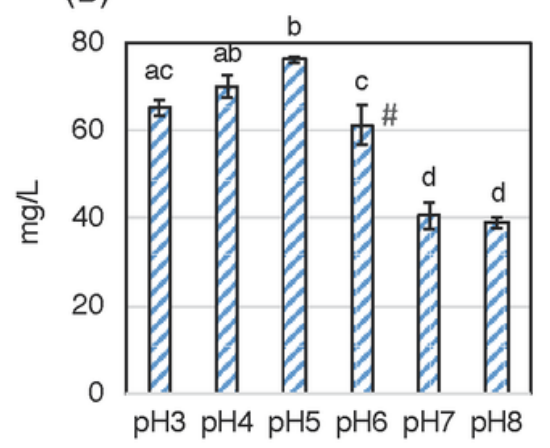

(C)

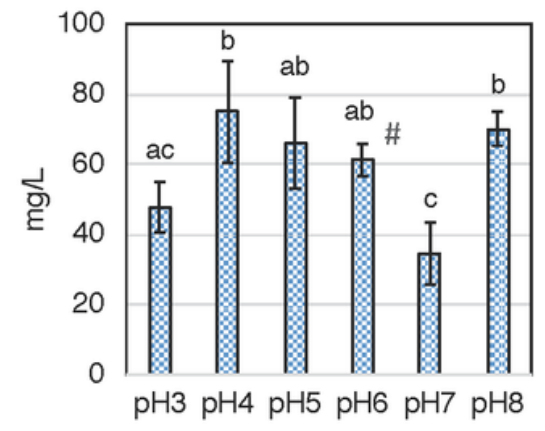

Glutamine

(D)

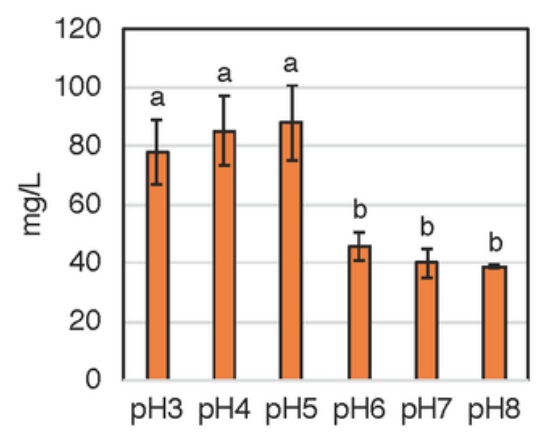

(E)

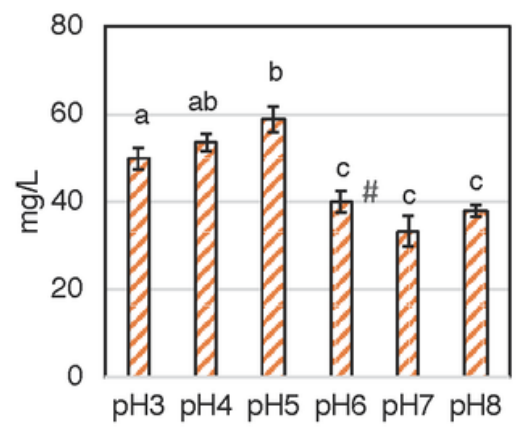

(F)

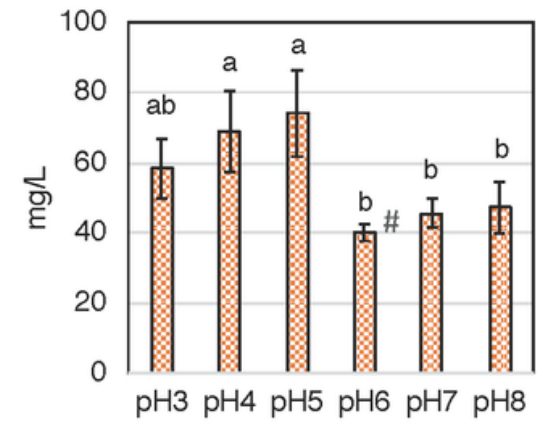




\section{Figure 1}

Levels of glutamate and glutamine excreted from E. gracilis following dark, anaerobic incubation. Glutamates $(A-C)$ and glutamines $(D-F)$ were obtained from the cells incubated in the GTA buffer $(A, D)$, citrate buffer $(B, E)$, and commonly used buffers $(C, F)$ at pH 3-8. Data are represented as the mean \pm SD for biologically independent samples $(n=3-5)$. Different letters indicate statistically significant differences (Tukey's HSD test; $\mathrm{p}<0.05)$. \#Same data of metabolite levels in the citrate buffer $(\mathrm{pH} 6)$ were used for $B$ and $C$ as well as $E$ and $F$, respectively.

\section{Succinate}

(A)

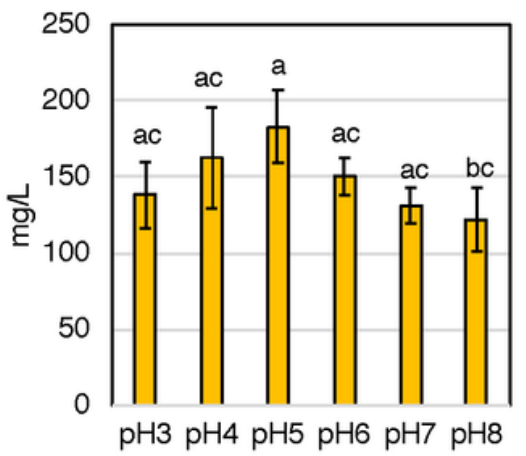

$\mathrm{pH}$ of the media

(D)

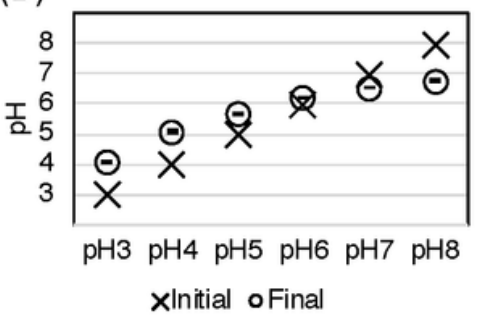

(B)

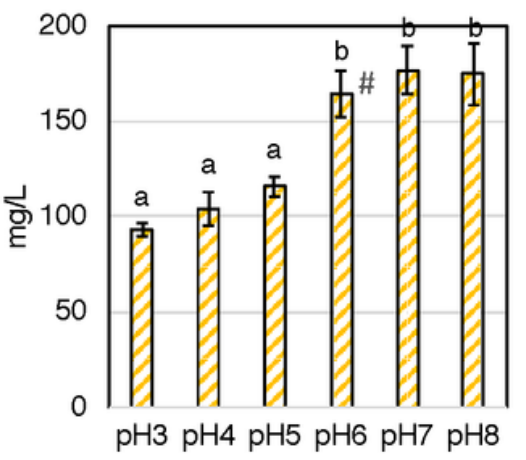

(E)

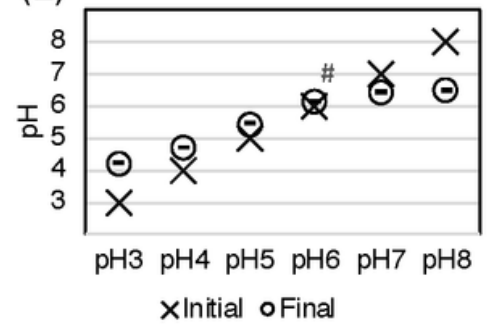

$\mathrm{NH}_{3}$

(G)

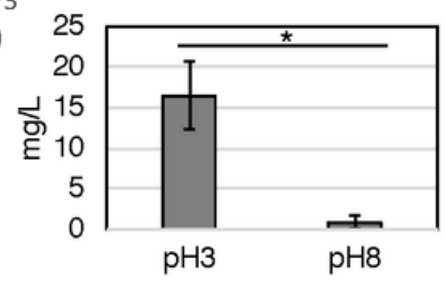

(C)

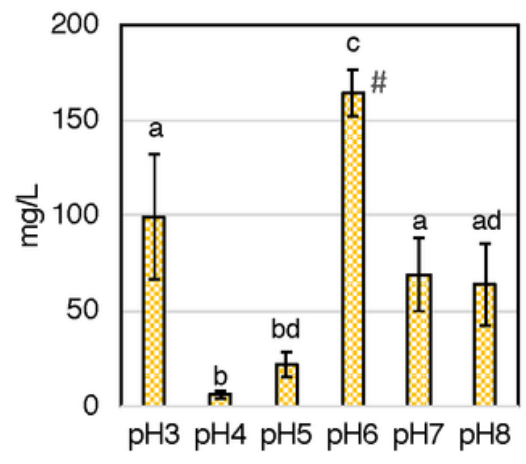

(F)

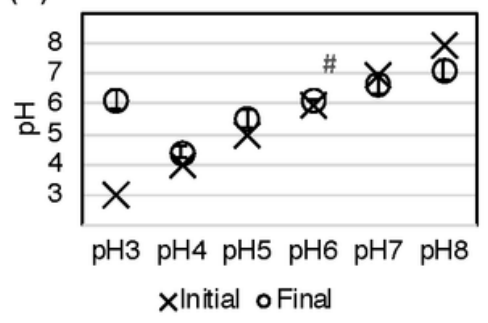

\section{Figure 2}

Levels of succinate and ammonium excreted from E. gracilis and $\mathrm{pH}$ values of the media after dark, anaerobic incubation. Succinates $(A-C)$ were obtained from the cells incubated in the GTA buffer $(A)$, the citrate buffer (B) or the commonly used buffer (C) at pH 3-8. The pH of the media before (designated as Initial) and after (designated as Final) were measured after cell incubation in the GTA buffer (D), the citrate buffer (E) or the commonly used buffer (F). (G) Levels of ammonium excreted from the cells incubated at glycine buffer $(\mathrm{pH} 3)$ or HEPES buffer $(\mathrm{pH} 8)$ were quantified. Data are represented as the mean \pm SD for biologically independent samples $(n=3-5)$. Different letters indicate statistically 
significant differences (Tukey's HSD test; $p<0.05)$ or an asterisk $(p<0.05)$. \#Same data of metabolite levels in the citrate buffer $(\mathrm{pH} 6)$ were used for Fig. $\mathrm{B}$ and $\mathrm{C}$, and $\mathrm{E}$ and $\mathrm{F}$, respectively.

\section{Figure 3}

Cellular morphology of E. gracilis under dark, anaerobic incubation. Representative cells incubated in the GTA buffer (A), citrate buffer (B), and commonly used buffer (C) at pH 3-8 were observed by microscopy. Scale bars represent $10 \mu \mathrm{m}$. \#Same data of the cells in the citrate buffer $(\mathrm{pH} 6)$ were used for $\mathrm{B}$ and $\mathrm{C}$.

(A)

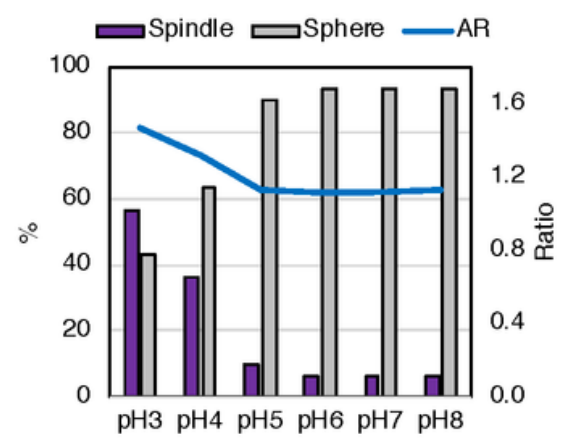

(D)

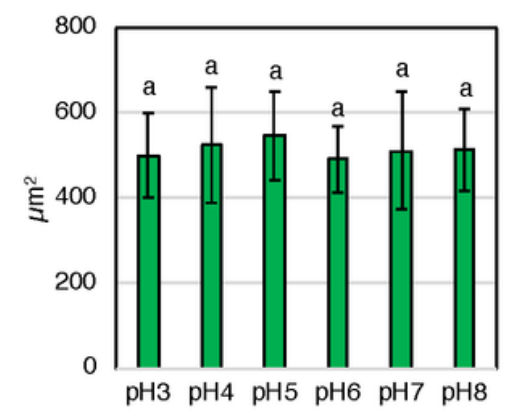

(B)

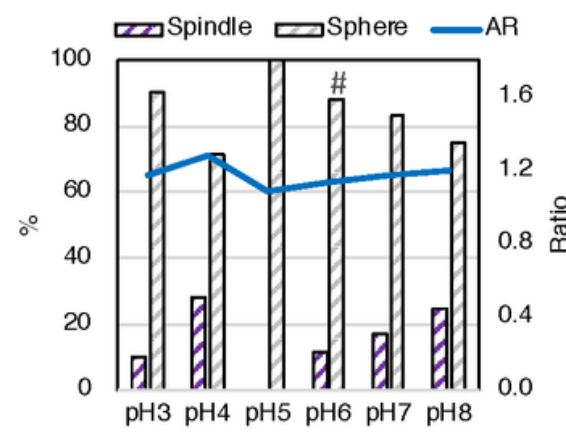

(E)

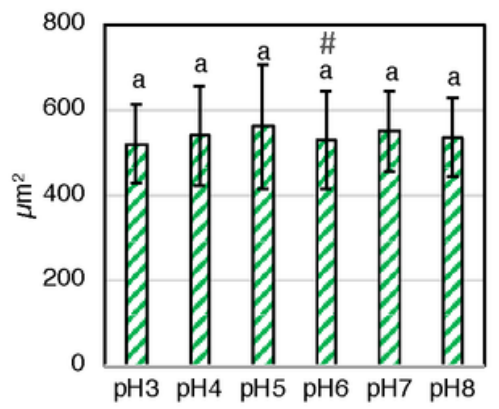

(C)

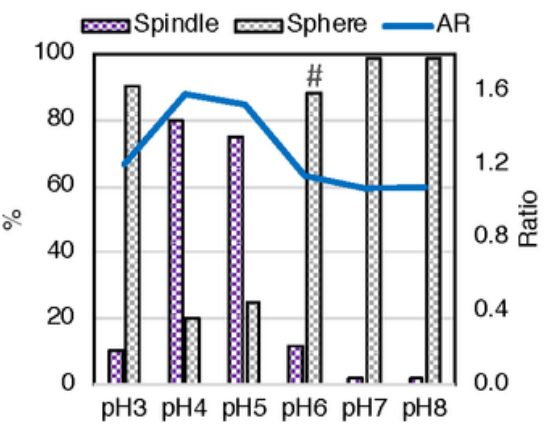

( $F)$

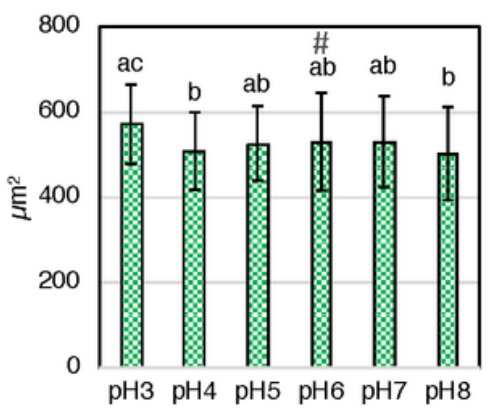

Figure 4

Observation of E. gracilis cells under dark, anaerobic incubation. Cell morphology was measured by microscopy and the parameters were calculated using the image visualisation software Image J. Data are represented as the mean $\pm S D$ for biologically independent samples $(n=60)$. $(A-C)$ The shape of the $E$. gracilis cells was considered as spindle if the length/width ratio, designated as aspect ratio (AR), was 1.3 or greater and was considered spherical if AR was less than 1.3. Cell areas were also calculated from the photographs using Image J. Data are represented as the mean \pm SD for biologically independent samples $(n=60)$. Cells incubated in the GTA buffer $(A, D)$, citrate buffer $(B, E)$, and commonly used buffers $(C, F)$ at 
$\mathrm{pH} 3-8$. \#Same data of the cells in the citrate buffer $(\mathrm{pH} 6)$ were used for $\mathrm{B}$ and $\mathrm{C}$ as well as $\mathrm{E}$ and $\mathrm{F}$, respectively.
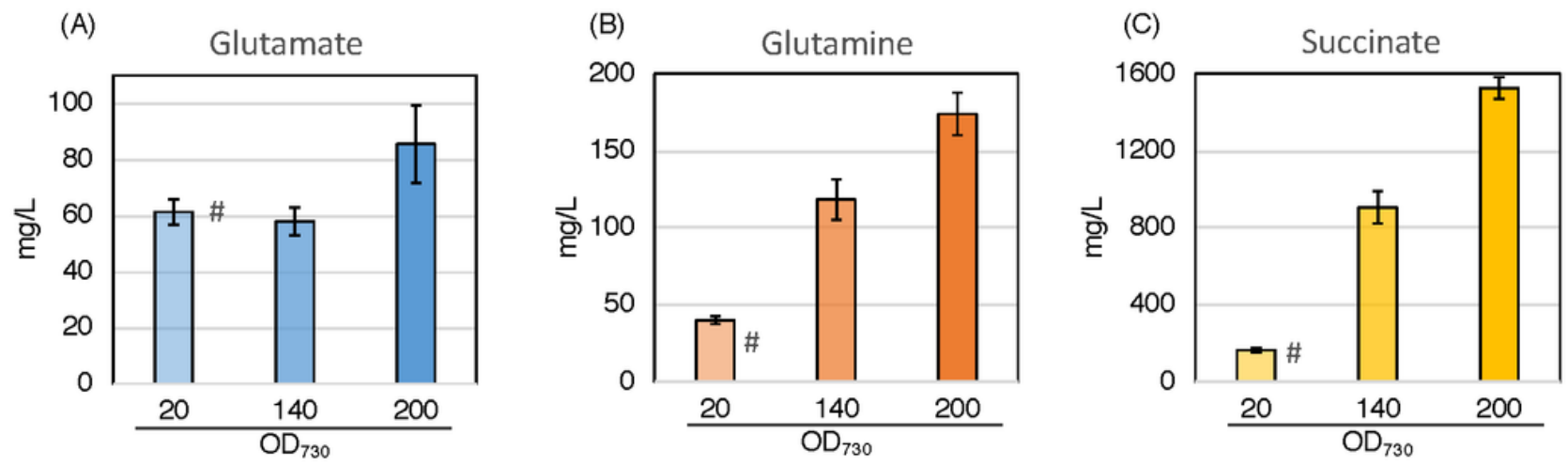

(D)

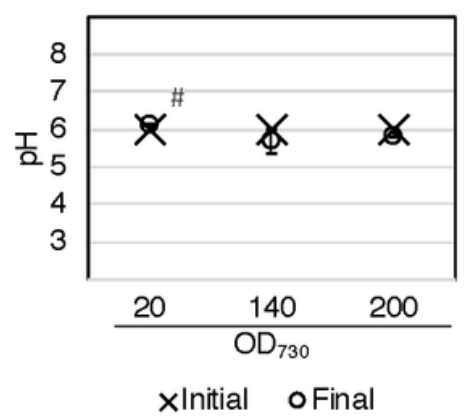

(E)
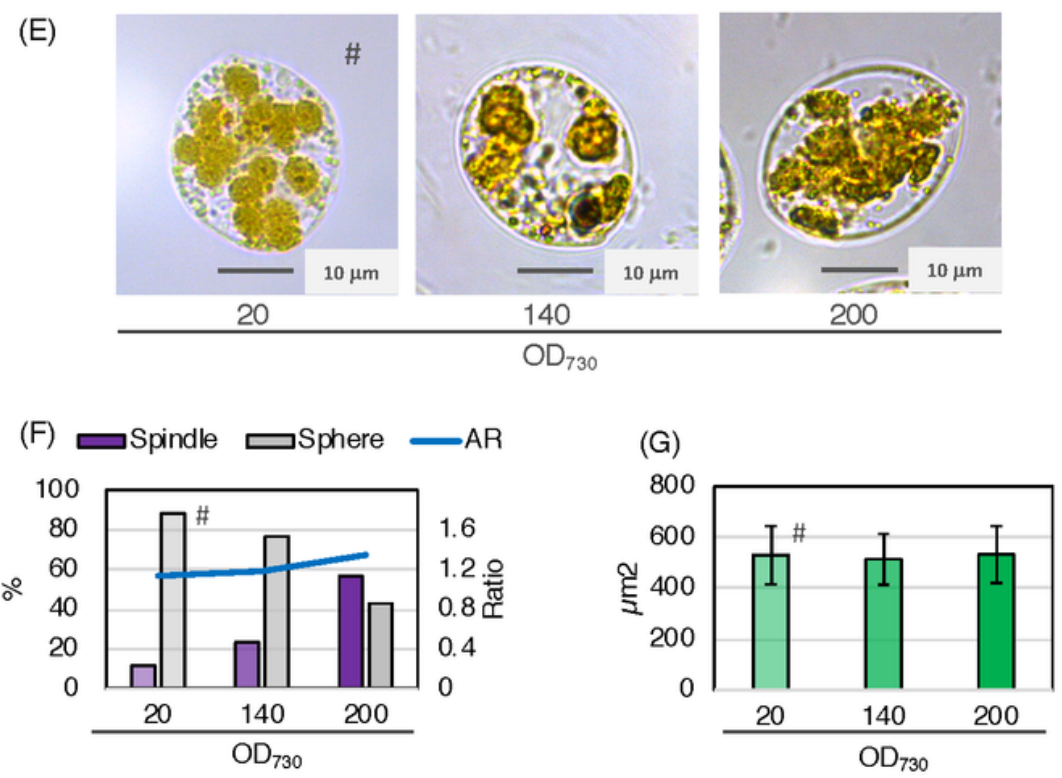

\section{Figure 5}

Density of E. gracilis cells under dark, anaerobic conditions. Cells (OD730 $=20,140$ or 200) were incubated in citrate buffer ( $\mathrm{pH} 6)$ for 3 days. Levels of excreted glutamate (A), glutamine (B), and (C) after incubation in dark, anaerobic conditions are represented as mean \pm SD for biologically independent samples $(\mathrm{n}=3)$. (D) pH of the media before (designated as Initial) and after (designated as Final) incubation were measured, and are represented as mean \pm SD for biologically independent samples $(n=$ $3)$. Cell morphology was measured by microscopy (E). A representative cell was chosen, and the cell shape $(F)$ and cell area $(G)$ were calculated using the image visualisation software ImageJ, and the data are represented as mean \pm SD for biologically independent samples $(n=60)$. \#Data of OD730 in Figure 5 are the same as that in Fig. 1-4. 
(A)

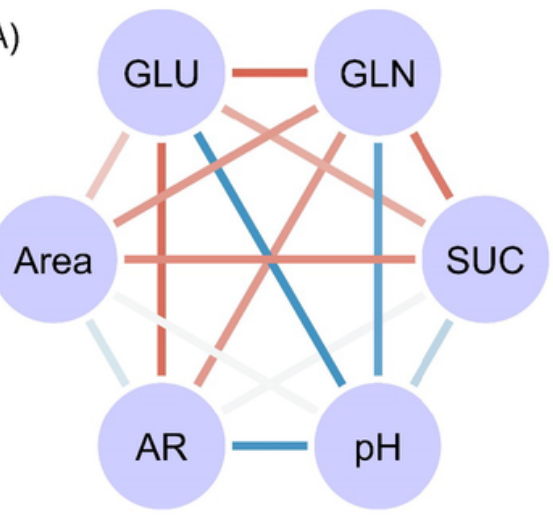

(C)

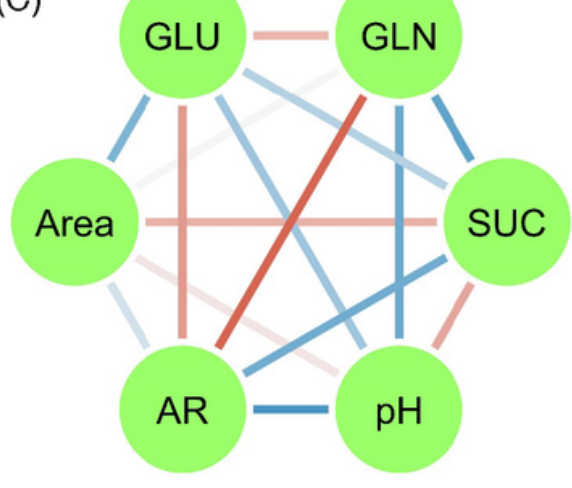

(B)
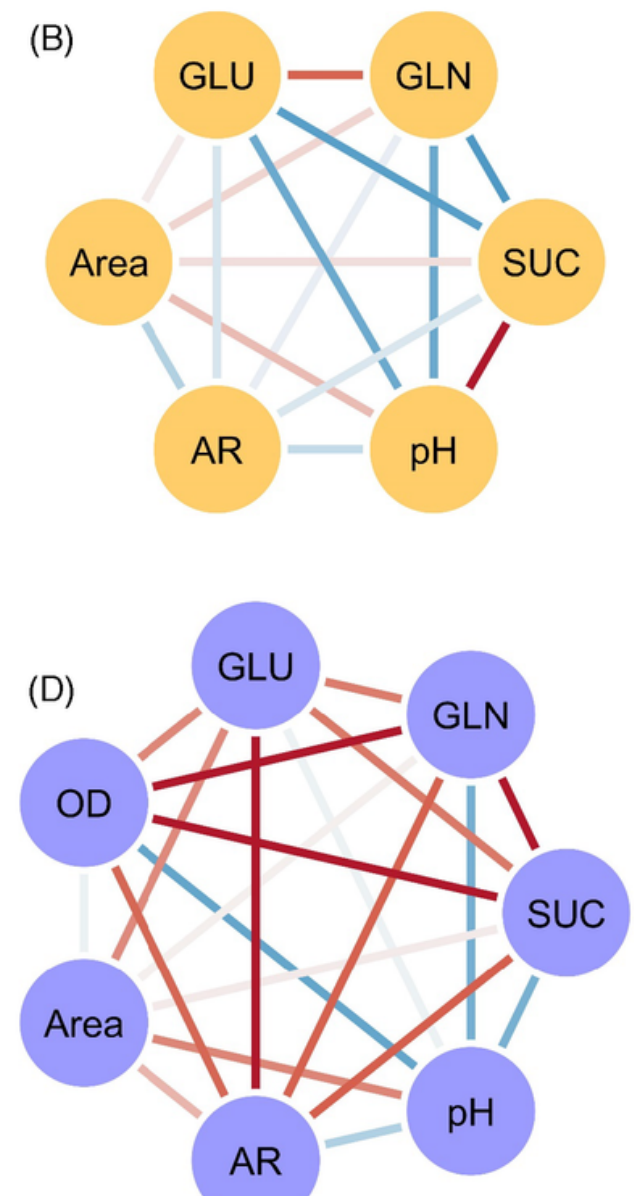

\section{Figure 6}

Correlation analysis of the metabolites, $\mathrm{pH}$ of the media, parameters of cell morphology and cell density. Positive and negative correlations are shown in red and blue lines respectively. Line density represents the degrees of the correlations, visualised by Cytoscape_ver3.7.2. Correlation analysis was performed using the data of cells incubated in the GTA buffer (A), the citrate buffer (B) or the commonly used buffer (C) at $\mathrm{pH} 3-8$ in Figures 1, 24 , and different cell densities in the citrate buffer $(\mathrm{pH} 6)$ in Figure 5. The numerical values of correlation coefficients are listed in Additional file 1.

\section{Supplementary Files}

This is a list of supplementary files associated with this preprint. Click to download.

- AdditionalFile1.xlsx 